\title{
FINNISH 20th CENTURY HISTORY IN ORAL NARRATIVES
}

\section{Pauliina Latvala}

On the break of a new millennium we are facing a question how does Finnish folk regard the passing 20th century. How have people survived changes in social and cultural life and how is it reflected in their family and kinship heritage. In 1997 the Finnish Literary Society organised a national competition of collecting heritage called "The Great Family Narrative" (Suvun suuri kertomus), which aimed to seek out the importance of family and native home for today's people. The competition resulted in more than 700 written responses. Below I intend to introduce the 20th century history of Finland on the very basis of these responses.

\section{THE HERITAGE REFLECTING THE FAMILY'S PAST RELATIVE TO HISTORY}

The heritage about family's past history progresses similarly to that of the established history. Both are created in a certain context and from a certain standpoint. Family heritage is formed through narrative history on the personal level, mediated by people's and their contemporaries' recollections. Seppo Knuuttila (1994: 23) argues that a problem here lies in the fact that people tend to alter the past in their stories, thereby creating a new reality. The current article deals with written narratives (see Apo 1995: 176) where recollections are somewhat more systematised than in oral narratives. It appears that in written form the respondent is more likely to follow the categories of official as well as unofficial history, which both create certain frameworks and models for the narration. The oral history is primarily defined as unofficial history. When presented in writing, however, oral history offers new interpretations of official history. History has been considered as the memory of society. The provided research material, however, suggests that in this case the memory must be selective. Personal memories and experience, different opinions on the same periods of time, events and people provide a versatile material for unraveling the past. 
In oral history the real and memorable past is often described as nostalgic and legendary, probably due to people's unconscious forgetting due to secondary influences. A narrative is always selective consisting of the moral values, attitudes and understanding of the past events of a given narrator. For instance, if we took to study the oral history of a small industrial region the narratives of people from the same generation but different occupational groups or socio-economic groups would differ considerably (e.g.: the narratives of the general manager of a factory versus those of workers; recollections of the worker's husband versus manager's wife, or children of the mansion versus the tenant's children, etc.). Similarly, there is difference between the official opinions of the 1918 Civil War and the recollections of soldiers of white and red forces (see Peltonen 1996: 242).

The study of the folkloristic aspect of heritage about family history widens our overview of general history. It also helps to observe the cultural phenomena from a different level. Studying family and kinship narratives reveals gradual changes in family ties and their relative importance, as well as changes in gender roles in a family. It also enables us study why the past is retold again and again and how the periodisation of history is carried out.

Only one part of family heritage is concerned with narratives about people the narrator has never really seen. Then, who are the characters in narratives of family heritage? Family heritage focuses on the aspects the narrator feels most characteristic to his background or supporting his identity. Thus the main character of a narrative could be a grandmother with her personal history but also a supposed forefather from the 17th century. Naturally, the everyday life of past centuries attracts interest; the study of kinship history of families aims to reach as far past as possible. The increasing fascination Finns appear to have with their past is proven by the facts that since 1970s the number of family reunions have multiplied, and that at the end of the 1990s Finland is the only country in the world to preserve its church registers in Internet (Spoof 1994: 7-9).

We should ask how the 20th century historical narratives reflect the general history? Just how do family histories differ from official history? For example, does the entire corpus view a unified 
narrative of the past, or is the past outlined and periodised according to certain established patterns in Finnish culture? The 20th century written narratives are first and foremost concerned with the following events: wars, ${ }^{1}$ emigration to America, transferring from country to cities and changes in life-style caused by urbanisation.

\section{EMIGRATION TO AMERICA IN FAMILY NARRATIVES}

During the pre-war decades and the war (1870-1944) nearly 400,000 Finns migrated from the country. More than half of them started off from Ostrobothnia where the birth-rate was extremely high at the end on the 19th century. Due to the local custom of primogeniture the younger sisters/brothers were forced to seek alternative ways of making a living (Korkiasaari \& Söderling 1994: 250-251). Individuals and society regarded migration quite differently. National ideology condemned the departure as a moral and economical loss, but the youth eager to leave associated America with changes and the widening of future possibilities (Haapala 1992: 29). Migration to America is often associated with the political action of the Finns: their settling in industrial regions strengthened also their sense of political belonging. Workers returning to Finland brought along ideas on civil rights and respective models of behaviour (Korkiasaari \& Söderling 1994: 251).

The background of those migrated to North-America has been described very differently indeed. According to the official history, the main reasons for migrating are the following: the boost in the United States economy, the impact of Russification in the early 20 th century and the recruitment of Finns to work as miners (Korkiasaari \& Söderling 1994: 251). The study of oral history, however has brought to light some more personal reasons for emigration. The contributors to the collection mainly focused on difficult relationships and how these compelled people to leave: sons run away to America to escape their stern fathers, or a father never returns home after having gone. Kirsi Pohjola-Vilkuna (1995: 63) argues that one of the most important reasons for going to America was divorce, legally justified by the infidelity of marriage partners or leaving one's wife or husband. Others left to escape being drafted 
into Russian army, or to go and earn money for buying a house or a farm, etc. Occasionally, unconventional stories turn up among the family histories:

Step-brother Ilmari left for America at the age of 18. He became a successful sheep farmer and raised a large family there. It seems that my mother and her step-brother Ilmari had had some kind of flirtation, because I inferred from my mother's stories that her brother had asked her to go to America with him (SKS.SUKU 512, man, age 57).

\section{WARS IN FAMILY NARRATIVES}

The Civil War (1918) gives added impetus to the theme of migration and the representation of 20th century Finns' history. A key motif in war accounts is a family member escaping death owing to his ingenuity. The accounts are particularly about the brave women in the family who rescue the prisoner by playing on the capturers' feelings. According to the narratives, guards had released prisoners when a woman had hurried there to say that a pregnant wife was about to into labour. Such courage could be explained by the fact that these heroic women were often acquainted with the captors; in other words, they may have been quite confident that a neighbour's son would be unable to kill the woman he knew since he was a child. Moreover, the accounts show that women were far from passive in the face of war:

Mother was baking bread when a "red" [communist] came in the house, rested his rifle's butt to the floor and declared: "I am the national power. In the name of national power I will confiscate this bread once it is baked." He then directed his rifle towards mother. Mother simply sneered and replied: "This national power must be really weak if it is supported only by your rifle." Taken aback and confused, the man mumbled: "I was told to say that, otherwise nobody would listen"(SKS.SUKU 22180, woman, age $70)$.

In the previous example, the behaviour of a soldier is hesitant and trained. The young recruited men are often regarded as casualties of war. According to the family narratives, the Civil War reached 


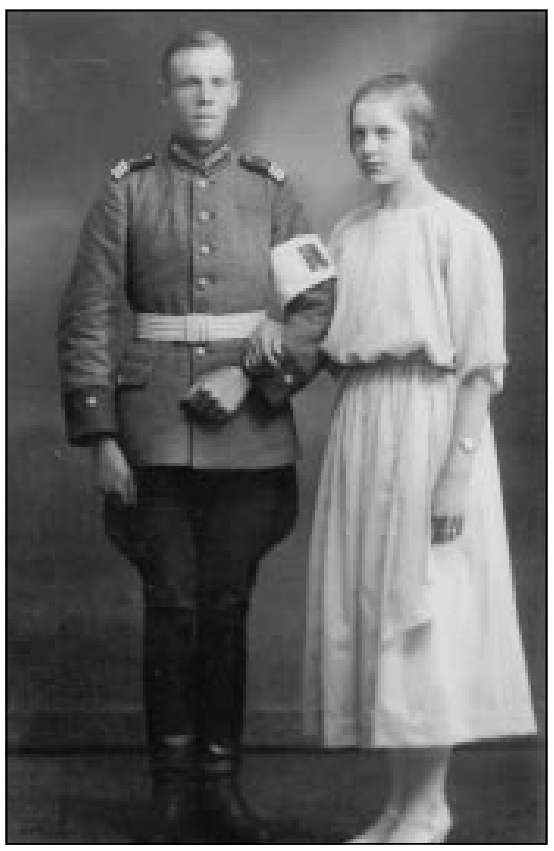

Photo. This wedding picture of my grandmother tells about the atmosphere during the Civil War (1918) in Finland.

the forest villages of central Finland quickly and relatively chaotically. The working class youngsters drawn into battle could not understand the consequences as well as could the politically active workers. Family narratives suggest that the working class consisted of both politically active men openly supported the rebellion and men who did not belong to organisations and would have preferred to avoid the violence altogether. Apparently the only way to escape war was to join the 'forest brothers' - patriotic partisans who hid themselves in the forests. Their life was not safe but appealed to many as reports of violent executions spread fast. They are also described in family narratives.

My grandmother told me a story about how a musician was unexpectedly substituted by another at her engagement party [kuuliaisissaan-kihlajaisissaan?-author's comment]. It turned out later that the young man who was playing before was taken outside and killed. In the summer his torn clothes were found behind the fence surrounding the field. And thus the Red rebellion had begun. (SKS.SUKU 6514, woman, age 54)

War-related narratives focus more on domestic situations than on the battle front drama. Even at home death was constantly lurking around, no-one knew when his/her close relatives could be struck down. As a rule, regarding close relatives on the battle front, the narratives only include the names, ages, death-places and the time of battle fought. The incidents, however, that took place at home are described in more detail. 
Those killed in battle were commonly brought to the homestead for identification and for the living to pay their last respects. These scenes are often described from the perspective of the bewildered child. In their accounts, women associate war with a shortage of grain supplies, endless work and lack of food. In some areas families could hire Russian prisoners-of-war as farmhands when their men were fighting on the front. This practice produced an absurd situation: farmer's wife and enemy work side-by-side on the farm as the farmer defends his country from the same enemy. Those who remained at home had a rather pragmatic view of putting the prisoners to work: after all help was desperately needed, and the young could even learn some Russian. The following example embodies the attitude of both parents towards the prisoners of war. The account does not indicate whether the father was home all the time or expressed his approval in letters or while he was on his leave.

My parents were both righteous people, their attitude towards the Russians and Ingrians was benign, in fact their situation was definitely better than that of our sons in battle. When the prisoners were sent back to their camp for replacement it was painful to see the tearful departure. They had become attracted to the family, and were most frightened and distressed about their uncertain future. (SKS.SUKU 2119, man, age 52)

According to the reader as well as to many of the respondents the most popular theme of war-related narratives was the relocation of Karelians throughout Finland during WW2. Family narratives view the evacuation and the concurrent conflict of different cultures from two viewpoints: those who left home and those who accommodated them or other village people. Even families with no direct experience of evacuation link this theme with the war.

Childhood war memories, the stories heard, personal losses and stories about heroic deaths of war lay bare human emotions in a starkly different manner than does the official history. Desertion narratives about evading reflect various personal attitudes towards the war: e.g. the experiences of actual deserters and those of relatives worried about concealing a family member. 
Maria told us about taking food to the hiding place dug in the floor of an out-building, looking for different excuses for going there. It was known that deserters were also being pursued by the authorities, but he was never found and he was never brought to the war tribunal, although he was in real danger on several occasions. (SKS.SUKU 2119, man, age 52)

The first part of the 20th century is associated with significant changes in society which concerned everyone. Since 1950s the time of narratives and family history is periodised according to the emergence of innovations and other things indicating economical welfare. During the post-war rebuilding period the daily lives of families revolved around welfare in both material as well as intellectual spheres. Obtaining a radio has been regarded as a sign of the improved economical situation by several respondents: several accounts describe the neighbours gathered around the respondent's radio, the only one in the village, to listen to the news. The radios were followed by television sets, refrigerators and cars. The mentioning of one's own house and summerhouse built at the side of the lake at the beginning of 1980s after describing the hard times is for a Finnish reader like a sign of a dream come true.

Family narratives include a number of accounts about the recent past. Still, how far back can we trace our family history? The question does not cease to intrigue us as at the turn of the millennium even the 20th century could be regarded as recent past. And the 19 th and 18th century remain even further to the past. The material studied in this article dates the reports heard from parents and grandparents back to the mid-19th century, although the main emphasis is laid on reports from the 20th century. Genealogical research, however, has reconstructed family history up to the 16th century.

\section{WHAT IS NOT TOLD IN THE 20th CENTURY ORAL HISTORY?}

The collection "The Great Family Narrative" remains conspicuously silent regarding children who were taken to Sweden as refugees, even though the 1940 census registers show that nearly 70, 000 children were evacuated to Sweden (Korkiasaari \& Söderling 1994: 
248).The majority were children from towns, mainly from Helsinki. As a rule they were from working class families between the ages of 5-8, although thousands of them were younger than 4 years and also older - schoolchildren (Edvarsen 1977: 172-174). ${ }^{2}$

Why does the current collection contain so little information about evacuation to Sweden? The majority of the respondents is born during the 1930s and the 1940s and thus could classify as possible evacuees. The reasons may lie in the following facts: most of the respondents were from rural regions (the evacuated children, on the other hand, were mainly from towns); some children may have even settled in Sweden if adopted; a part of the children suffered from illnesses when they left Finland and a number of them died in Sweden. The younger children who did finally return to Finland can hardly remember their evacuation, also the experience might have been too distressing to deal with. It has been argued that it was not caused so much by going to Sweden but the return to impoverished Finland. As a rule, the Swedish families who accommodated the evacuees were relatively well-off and children have enjoyed the more comfortable living-standards as well (Edvarsen 1977: 90 ). Another problem was unfamiliar people and the strange language. In addition to the above-mentioned reasons for the lack of information about this topic in "The Great Family Narrative" is that the collection competition aimed at collecting success stories - one's childhood in a strange country hardly qualifies. On the other hand, the life stories of Finns often begin with the "poor and impoverished childhood" (and during the course of these narratives the poverty is overcome). Therefore, I assume that the respondents could have narrated more about evacuation. Also, it is not possible that the topic was left out because it had been collected in previous years. Instead, it has been covered in photography; exhibitions have brought memories back to life and may have inspired its publication via different forms of culture. The scarcity of information as compared to the subject of migrating to America, might also be due to the fact that people were taken to Sweden as children, but they went to America as youngsters or adults.

Although other 20th century Finnish wars get their due attention, the present material consigns the Lapp War (the WW2 events in northern Finland) to absolute silence probably caused by the ten- 
dency in literature and research reports to focus on other wars. The 1918 Civil War and the retreat from Karelia during WW2 is quite well covered but the narratives by North-Finnish barely touch the Lapp War. Although "The Great Family Narrative" points out the fact, the corpus still focuses more on the southern heritage. Often, the questionnaire supplementing the competition functions as a framework for the narrative. The questionnaire under discussion contained no direct questions about war: the only one referring to war was: "What do people tell about times of war and crises?"

The family history collected most recently remains largely silent about the 19th century, and more silent regarding the earlier periods. The most momentous period in the 19th century was the famine of $1860 \mathrm{~s}$. Regionally, the famine was worst in North-Finland, the starving population headed southward where there was more food available. A number of accounts about events that happened to earlier generations could be found; however, I have not included them in my treatment, as the material under discussion centers on the events of the 20th century. The death rate during the famine was considerably higher than during WW2 or the 1918 Civil War (Juva \& Juva 1992: 424). Therefore, it provides sufficient material for narration; the period of famine has been considered as one of the most disastrous periods of recent history. If the narrative is taken further back in time, and the person immediately undergoing the narrated event is, say, the grandmother of the narrator's father, then the heritage acquires a novel representation where one event is compared to the analogous hard times of others:

My father told stories he had heard from his grandmother Eeva about the famine of the 1870s similar to those described in history books. About peeling the bark off pine trees to make false bread, gathering moss, slaughtering the whole herd when the cattle had nothing to eat, feeding thatched roofs to animals... He spoke about plague and other pestilence, beggars frozen to death in snowdrifts. Father said that these times must have been much worse than, for example, during the crisis of 1930s or WW2. (SKS.SUKU 235, woman, age 65)

The 19th century Finnish history also comprises the Finnish War (1808-1809); this collection, however, contains no accounts of it. 
The 18th century is characterised as a period of great feud (17001721) when the army of Peter I invaded Finland. On the basis of the interviews with the respondents, our more detailed analysis below aims to find out their awareness of the period previous to the 20 th century.

In addition to narrating the events of official history, oral narratives include descriptions of domestic everyday life. Below I intend to focus on what the Finnish talk about their domestic life.

\section{ACCOUNTS OF FAMILY AND DAILY LIFE}

The majority of the Finnish who participated in the competition "The Great Family Narrative" have personal experience of a family structure larger than the nuclear family, having worked at the farm from dawn till dusk and experienced the isolation from the rest of the world as well as the sense of belonging characteristic to living in a large family. The homes of the families described in the narratives were places which held together children and grandparents, often the unmarried sisters and brothers or other relatives and orphan children. Sometimes, they accommodated also travelling workers and peddlers.

There were always single homeless people in the neighbourhood, mostly men, who were not drunkards, and who went from farm to farm. - Every farm had a bed for people like that, they slept their night there and then left the farm, and they did not have to pay for it. The family seldom disapproved of such habits. According to the tradition, a traveller was entitled to spend the night at a farm without asking for permission. Sometimes they did even some work, say, a cobbler made shoes and others helped out with making hay. (SKS.SUKU 11537, man, age 67)

Thus today's notion of the family home as a largerly private realm was almost non-existent in the lives of many of the writers. How do women describe daily family life and the position of women in their society? What is valued when it comes to family life? Do the narratives include accounts of seeking happiness and good personal relationships? Do they describe affection between men and women? The narratives concerning marriage and personal relationships give 
a characteristic picture of the tradition and customs of starting a family in the early 20 th century. In brief we might say that partners were found from their own neighbourhood, the dating period before marriage was relatively short, and the buying of engagement rings denoted serious intentions. The first child was born during the first year or two of wedding at the latest - more commonly, the weddings were announced as soon as the pregnancy began to show. The young couple moved in with the husband's family where the wife acquired the status of a daughter-in-law, or, the couple settled in a tenant house.

How was life different for family members of different age and roles. According to women's narratives the childhood memories are generally positive, although filled with work. Tending cattle and domestic chores helped to build a sense of duty and responsibility, and such childhood tasks prepared them for their future life. The course of life for women in the village community was quite predetermined, largely depending on the necessities of the child's family: they had to work outside the home from an early age to feed the growing brothers / sisters. Also, their educational and marriage matters were previously settled by their fathers.

Over all, the material offers a relatively gloomy picture of family life. There are very few accounts which would describe emotional affinity, the reader has to specifically look for it in the material as it is never explicitly expressed. The close tenderness is generally characteristic to one of the parents or grandparents of the narrator, often mother or grandmother. Marriage seems less important in that sense, in most cases only the number of children is mentioned. The same applies to stories about husbands. From the wives' standpoint, it is often the husband who has made married life worse, either by his drinking, violence or emotional instability. Men, however, never express any dissatisfaction with their wives. True, some instances of broken relations can be found in the material. The following extract is a rare example of tolerance regarding infidelity:

In the Sami community people don't know what jealousy is. Nobody even raised a fuss just because a child happened to look like the neighbouring farmer. (SKS.SUKU 11538, man, age 67) 
The treatment of the life of women in the village communities centers on the large number of children in the families and the role of women in family life. The experience in sexual relationships and growing into women is best expressed in the values and standards instilled in the daughters of the family.

In my childhood attending school was not very common. You were lucky if you could go to the primary school. After that girls had to go to work as maids. Only the daughters of larger farms could stay home and wait for suitors. (SKS.SUKU 8740, woman, age 72)

For some girls being employed as a maid also meant certain adapting to the house rules. A common phenomenon among the farmers and their sons was a sc. culture of sexual boasting which included bragging about sexual conquests and the "trying out" of maids or the sexual "right to use" (Pohjola-Vilkuna 1995: 104-105). The material alludes to incidences of intimate relationships with the heads of the household, often described by relatives in a very indirect manner. The narratives describe the custom of men sleeping with the maids on his farm, followed by the account of a grandmother who was once fired from her jobs as a maid and her search for a new position with a child; we can only speculate on what happened. A farmer's daughter born in 1928 describes the expectations towards women as follows:

In my family, men have generally been considered more important than women. In a way, the women have to live their lives through men by sacrificing their own lives to serving their husbands and family. Education was not considered important for women. You had to be prepared to do all kinds of physical work, without having a say in the matter and without receiving any payment - single girls had to stay home and work as maids if their parents so insisted. (SKS.SUKU 9835, woman, age 69)

The material under discussion contains a number of similar examples, whereas the accounts are not embellished:

Daughters were never esteemed in the family the way sons were. If a girl was lucky to marry a rich man, she received more respect from her own family. Husbands seldom regarded their wives as human beings. (SKS.SUKU 4698, woman, age 71) 
The above examples about domestic life and the family roles lead us to the topic of daily life. Those seemingly trivial and banal incidents, or so to say common everyday life, are often discarded by researchers who tend to look for exceptional and vivid descriptions. Nevertheless, we should look more into daily life, as we generally know nothing about it (see Lehtonen 1996: 13). Laura Aro (1996: $65)$ classifies among other things the report narratives, established or personal opinions and arguments as well as ethnological descriptions as types of the daily narratives often ignored in anthropological and folkloristic research. These types generally are discarded from closer analysis as being less narrative by nature.

Reading accounts of daily life we will understand the extensive cultural changes that took place in Finnish society during the 20th century. The depiction of daily life also reflects the modern views on previous times and the contemporary life-style. The peasant community of Finland has been characterised by regional isolation and the idyllic charm of privacy, by an image of a small and poor tenant farm with a large family and its wholeness symbolising the overcoming of hardships by mutual hard work. On the one hand, the narrators of oral history who have experienced the daily life of village communities tend to focus on such somewhat nostalgic stereotypes, on the other hand, their narratives reflect another side of this phenomenon. Particularly, the recollections of those narrators who were young during 1950s suggest the relative importance of belonging to urban or rural community described by social relations and every-day life. Among other things the respondents sketch the rural stereotypes of 'genuine' townsfolk, which clearly indicate the envious and hostile distinction between "us" and "them". Such differences in mentality is also expressed in the attitude towards people who left their home villages to settle in towns. Such people were called pakenioitsijoiksi "the deserters" and työtä vieroksuviksi hienostelijoitsijoiksi "work loathing dandies". On the other hand, urbanisation was associated with educational and occupational progress enabling consumption and the acquisition of property. A relative's education and success was seen as an honour to the whole family, irrespective of the fact that it emphasised one's own lack of education: 
People started to greet me only after my graduation from a trade school, and after my son became the first one in the family to wear the white graduation hat, it seemed to provoke both admiration and envy. (SKS.SUKU 3424, man, age 64)

In addition to the national differentiation between "us" and "them", the family narratives also voice people's attitudes towards the neighbouring country, Russia (Soviet Union). The relations between the Finns and the Russians are repeatedly described in the Finnish family narratives. Due to its geographical position Finland has been strongly influenced by events in Russia, even decades after gaining its independence. Russia has also occupied people's minds; the old sayings like ryssä on ryssä vaikka voissa paistettais "A Russian is a Russian even if he's fried in butter" or Venäläistä viekottele, pidä veitsi vierelläsi "While flattering a Russian keep a knife handy" refer to the national prejudices towards the Russians (see e.g. Kuusi 1954: 54).

The modern concepts emphasising privacy at home, in family and daily life suggest that the privacy in family life described in the current material differs considerably. Nowadays, nuclear families seldom include grandparents, not to mention other relatives. Social distance between parents and adult children have increased relative to the growth in geographical distances. The family is a private establishment, even the number of different types of family is larger than before. The family and working life provides that the family is based on a certain level of education and position, at the same time they have to be in balance.

Family narratives make up an intriguing material for looking for references to how people have adapted themselves to cultural changes. Have the rural people who settled in towns felt rejection, and how the transference and other changes have influenced individuals? The problem of transference is most eminent in the individual sense of regional identity. Some people feel a strong longing towards their native home, after years of living in town they have retained their sense of being a native of Savo or Karelia. The emotions associated with visiting home are described by saying that the hearing of one's native dialect symbolises their "coming home". The narratives also imply that those who came to towns to study or work could not escape the syndrome of "the soul of time": those 
who left country-side move as if between two worlds whereas the previous life seems more simple and clear: the family functioned according to the established and simple pattern of distributed roles, there was no need for choosing occupation or dividing oneself between work, family and leisure. On the other hand, the changes in family and work life have contributed to making life easier for future generations.

\section{THE RELATIVE IMPORTANCE AND CHANGES IN FAMILY STRUCTURE}

Changes in family structure are yet insignificant. How can the importance of being a part of a family alter in the changing society? In village communities the ancestry determined social position and opinion: each family member had an obligation to keep up the reputation of a family. The importance of family's reputation is pointed out more specifically in views towards marriage: the bride was chosen from a hard-working and noble family, the groom was valued according to the economical stability and acceptable social position of his family.

The current material suggests that the reputation of a family was a public matter in village communities. Everybody knew each other and families were compared for general as well as match-making purposes. People talked about the girl's marrying into a certain family, also about girls who married drunkards or violent men. Depending on the situation the marriage was made public or hushed up. The unwelcome suitors and pregnant girls were turned down by offering them money.

What is the importance of family ties today? The hidden levels of narratives reveal that they are told according to a certain linear pattern: the main characters are either the narrators themselves or their parent or grandparents. In narratives, especially those written by women, women are valued more than in traditional family narratives. Difficulties concerning the tracing of female lineage are explained by the lack of information in historical sources, and the role of women as compared to the role of men is reduced to a mere hint. ${ }^{3}$ In the current narratives, particularly those written by men, the daughters are not regarded as those taking over the 
family. The male-centered narrative is also dominant in Estonia: forefathers are better known and could be traced further back than women (Jaago \& Jaago 1996: 129).

The idea of male lineage originates in the tradition of naming the children after their father, therefore, for the daughter's successors the line seems broken by a different family name. Strangely enough, people determine ancestry on the basis of the family name and male-lineage. If so, the daughter's descendants carry her genes, character and features as well.

The family narratives written by men are characterised by tracing the ancestors on the basis of native home, determining the territory owned by the family, the proprietary and inheritance relations, but also finding the ancestor. The ancestor, usually a prominent man, is traced back as far as possible. In genealogical research an ancestor can be, for example, a clergyman who stood up for peasants during the 16th century Club War (1596-1599). The narratives written by women feature mainly commonplace heroes, ordinary men and women who feed and support their large family and cope with difficulties. Women's narratives tend to focus on describing family relationships as well as on reconstructing their parents' life stories.

The material under discussion provides no further explanation for the origin of family name, with a single exception where the origin of the name is interpreted as mythical:

... some narratives argue that not all the Pulkkinens are relatives, it is said that in ancient times they were a community, tribe or a respective group. The name comes from a stick or some other stake-like object. The same staff used to be the symbol of the tribe. (SKS.SUKU 22988, man, age 73)

The lack of roots and the emotional distance from one's native home, both very topical issues in 1990s are also referred to in the discussed material. For example, a second generation Karelian emigrant says he feels himself a part of "the nation with no place in the world", who is influenced by stories about Karelia, and although never having even been to Karelia he is drawn there the way his parents are. According to him one of the most important precondi- 
tions for finding one's 'roots' is that the older generation introduces the younger ones with the history related to this specific family by showing the fields and farm buildings or other objects associated to the past stories. But it is not only the Karelians who feel themselves 'rootless'. Some people have never been told about the family's past, and often it holds little interest for them, by getting older their interest is revived but the narrators who know have passed away by that time.

The importance and affinity of family differs from person to person, the only certain tendency is that by getting older the interest towards one's origin grows. The youth have compensated the issue of their origin with friends and smaller social groups. At the same time people are interested in keeping their family unity and traditions alive. One of the most expressive examples here are the family albums in Internet, providing private information via multimedia: presenting photos of the house and members of the family supplemented by comments on their activities, the recordings of children's singing, etc. ${ }^{4}$ Next to the unity in family, few narrators have also expressed the significance of privacy and belonging in the family; a female respondent, for example, has said:

I have never regarded myself as individual, but as a member of my family. (SKS.SUKU 6518, woman, age 54)

Translated by Kait Realo

\section{Comments}

${ }^{1}$ The Civil War in 1918, the Winter War and the War of Continuation 1939-1945.

${ }^{2}$ The statistics includes children from poor families only, the more well-off children were usually taken to their relatives.

${ }^{3}$ See Siukkonen 1998; the article contains references to the report by Spoof (1994).

${ }^{4}$ See e.g. Internet search for "family albums", or: http:// www.syspac.com/ robh/ or http://www.flash.net/ jcraig38/ album.htm or http://views.vcu.edu/ hubbard/family.htm 


\section{References}

Apo, Satu 1995.Naisen väki: tutkimuksia suomalaisten kansanomaisesta kulttuurista ja ajattelusta. Helsinki.

Aro, Laura 1996. Minä kylässä. Identiteettikertomus haastattelututkimuksen folklorena. Helsinki.

Edvarsen, Annu 1977. Sotalapset. Jyväskylä.

Haapala, Pertti 1992. Suomalaisen yhteiskunta.Itsenäistymisen vuodet 1917-1920. 3. Katse tulevaisuuteen. Helsinki.

Jaago, Tiiu \& Jaago, Kalev 1996. See olevat olnud... Rahvaluulekeskne uurimus esivanemate lugudest. Tartu.

Juva, Einar W. \& Juva, Mikko 1992. Suomen kansan historia. III. Ruotsin ajan loppukausi. Helsinki.

Knuuttila, Seppo 1994.Tyhmän kansan teoria. Näkökulmia menneestä tulevaan. Helsinki.

Korkiasaari, Juoni \& Söderling, Ismo 1994. Muuttoliike. Suomen Väestö. Hämeenlinna.

Kuusi, Matti 1954. Sananalaskut ja puheenparret. Helsinki.

Lehtonen, Mikko 1996. Merkitysten maailma: kulttuurisen tekstintutkimuksen lähtökohtia. Tampere.

Peltonen, Ulla-Maija 1996. Punakapinan muistot. Tutkimus työväen muistelukerronnan muotoutumisesta vuoden 1918 jälkeen. Helsinki.

Pohjola-Vilkuna, Kirsi 1995. Eros kylässä. Maaseudun luvaton seksuaalisuus vuosisadan vaihteessa. Helsinki.

Siukkonen, Timo 1998. Naisia syrjitään sukututkimuksessa. Helsingin Sanomat 3.08.1998.

Spoof, Sanna-Kaisa 1994. Sukuseurojen perustamisen aaltoliikettä. Sukuviesti nr. 6. 1994. 